\title{
Soft tissue changes after anterior maxillary osteotomy by using 3D CBCT scanning.
}

\author{
Cambios en los tejidos blandos después de la osteotomía maxilar anterior mediante \\ el uso de la exploración 3D CBCT.
}

Ahmed Fathi AL-Omar ${ }^{1}$ \& Usama AL-Dakroroy ${ }^{2}$.

AL-Omar, A.F. \& AL-Dakroroy, U. Soft tissue changes after anterior maxillary osteotomy by using 3D CBCT scanning. Int. J. Med. Surg. Sci., 4(4):1245-1250, 2017.

SUMMARY: The objective of this study was to evaluate the soft tissue changes after anterior maxillary osteotomy using cone beam computed tomography. The study included twelve patients diagnosed as suffering from an excess of the anterior part of maxilla and required surgical correction by anterior maxillary osteotomy. Assessment of Cone beam computed tomography in evaluation the soft tissue changes. All cases subjected to anterior maxillary osteotomy using modified Cuper technique. Follow up of cases was does clinically and radio- graphically by cone beam computed tomography. The results of the study proved that the statistically significant increase in mean Nasolabial angle after 6 months was 5.2 degrees, the mean value of nasal width after 6 months was $0,9 \mathrm{~mm}$. The mean value of Philtrum length was $3.3 \mathrm{~mm}$. In conclusion, Cone Beam Computed Tomography can be used to obtain dimensionally accurate linear and angular measurement from bony maxillofacial structure and landmarks and allows accurate, three-dimensional imaging of hard and soft tissues.

\section{KEYWORDS: Cone beam computed tomography; anterior maxillary osteotomy; soft tissue; class II skeletal problems.}

\section{INTRODUCTION}

Dento-facial deformities affect approximately $20 \%$ of population. Patient with dento-facial deformities may demonstrate various degree of functional and aesthetic compromise (Wilmot et al., 1993). Such malformation may be isolated in one jaw, or may extent to multiple craniofacial structures. They may occur unilaterally or bilaterally and may be expressed to varying degree in the vertical, horizontal and transverse facial planes (Kiyak et al., 1988). Many patients with dento-facial deformities can benefit from orthognathic treatment (Finlay et al., 1995). Orthognathic surgery is the art and science of diagnosis, treatment planning and execution of treatment by combining orthodontics and oral and maxillofacial surgery, to correct musculoskeletal, dento-osseous, and soft tissue deformities of the jaw and related structures. (Ouellette, 1978). The first to perform the anterior maxillary surgery was Cohn Stock in 1921 (Fonseca et al., 2012). A wedge shaped segment of bone was excised from the maxilla through a transverse palatal incision. Relapse occurred after four weeks because the segment was mobilized by green stick fracture. Subsequent relapse after removal of the fixation was noted which was due to inadequate mobility gained from the operation. Polton (1976) greatly popularized and improved the surgical correction of anterior maxillary excess. He advocated complete tunneling of mucoperiosteum both labially and palatally through two labial vertical incisions. In 1954, Cupar (1954) created the "Down-fracturing" technique which provided direct access to the superior maxilla and excellent visualization of the bony area. In an effort to facilitate removal of bone at the junction of the septum and the superior surface of the palate, Wunderer (1962), proposed reflecting a palatal flap.

Use of Anterior maxillary osteotomies for correction of open bite, closed bite, underdeveloped maxilla, and protruding maxilla was advocated by Mohnac (1966). The procedure could be used concurrently with mandibular correction of class-II and class-Ill malocclusions. According to Parnes, the major advantage of surgical correction over the conventional orthodontic treatment was the "time factor". (Wilmot et al.)

Radiological imaging is needed to determine the presence and extent of diseases, for treatment planning, to monitor disease progression and to assess

\footnotetext{
1. Assistant Consultant Department Of Oral and Maxillofacial Surgery king Khalid University Hospital, Dental University Hospital Faculty of Dentistry, King Saud University.

2. Lecturer of Oral and Maxillofacial Surgery, Faculty of Oral and Dental Medicine, Must University.
} 
treatment efficacy. Before radiological imaging can be performed a detailed patient history and clinical examination are needed. The findings can then be used to select the most appropriate type of radiological examination. (White \& Pharoah, 2008; Boeddinghaus \& Whyte, 2008)

Cone beam computed tomography used in oral and maxillofacial (OMF) surgery and orthodontics for numerous clinical applications, particularly for its low cost, easy accessibility and low radiation compared with multi-slice computerized tomography (Babba et al., 2004).

The use of CBCT technology in clinical practice provides a number of potential advantages for maxillofacial imaging compared with conventional CT: High resolution, lower radiation dose than MSCT, easy accessibility, easy handling, 3D dataset, and real-size data, potential for generating all 2D images. (lateral ceph., TMJ), potential for vertical scanning in natural seated position, less disturbance from metal artifacts, reduced costs compared with $\mathrm{MSCT}$, digital imaging, user friendly post processing and viewing software. (Flygare \& Ohman, 2008; Ganz, 2008)

\section{METHODOLOGY}

This study was conducted on twelve adult patients, with age ranging from 21 to 27 years, average 24 years and average over-jet $9 \mathrm{~mm}$. The patients were selected from the Outpatient Clinic of Oral Surgery Department, Faculty of Oral and Dental Medicine, Cairo University. They were selected on the basis that main problem was an excess of the anterior part of the maxilla and required surgical correction by anterior maxillary osteotomy. For each the following data were recorded: History, clinical examination, dental radiographic examination, orthodontic casts and mock surgery, photograph, cephalographs, cone beam computed tomography.

Complete personal and relevant medical and dental histories were recorded; Clinical examination of the oral structures was undertaken in a systematic fashion. Lips, cheeks, tongue and palate were examined. Competence, texture and behavior of the lips were investigated. The position of the tongue at rest and function was evaluated; number, state, and position of the teeth were checked.

The full face of the patients was examined from frontal and profile direction. Any degree of facial asymmetry or abnormality was observed. Vertical, antero-posterior, and transverse relations of dental arches were assessed to evaluate the degree of overjet, overbite, lower facial height, and anterior or posterior cross bite.
Photography in this fixed position was taken three times. One before orthodontic treatment if it was needed, the second after orthodontic treatment and Last one was taken one year post- operatively. Photographs of the occlusion were taken from frontal and absolute lateral direction before and after orthodontic treatment and before and after surgical treatment. In each time a fixed distance from the camera to the patient's face was used. The pre-surgical model was used for prediction of post-operative position of the dentition.

Diagnostic, preoperative and postoperative after one year. Using Scanora machine CBCT (Soredex, Palodex Group Oy, Nahkelantie 16, Finland). Were made with the same target to film and subject to film distances. These CBCT were made with patient in centric occlusion and lips in repose. Hard and soft tissue land marks were located in all tracing with stable reference lines. Anatomical bony landmarks, vertical and horizontal lines.

\section{Pre-surgical orthodontic stage}

The purpose of this stage was to level and align the dentition. Orthodontic plan was established guided by surgical needs for occlusal preparations. Expansion of the maxillary inter-canine width was necessary to permit post-surgical relocation of the anterior segment of the maxilla in proper alignment with the corresponding segment of the mandibular arch.

\section{Surgical Stage}

The surgery was performed under general anesthesia when indicated supplemented by local anesthesia infiltrated locally for hemostasis.

A buccal vestibular incision is created, allowing direct access to the anterior lateral maxillary walls, piriform aperture, nasal floor and nasal septum then the nasal mucosa is elevated from the superior surface of maxilla. Complete separation of the septal cartilage from the maxillary bone using a nasal septal osteotome. (Fig. 1)

Fig. 1.

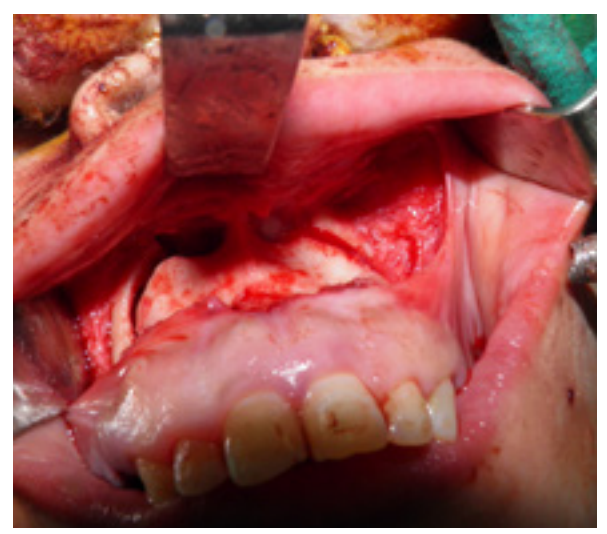


Complete tunneling of mucoperiosteum both labially and palatally at the first premolars to get access to maxillary bone and to preserve vascular supply to the mobilized dento-alveolar segment. The tooth planned to be removed usually the first premolar was extracted. The vertical osteotomy is then performed bilaterally between the teeth opposite to the extraction socket. The horizontal osteotomy is completed, the horizontal cut was about $0.5 \mathrm{~cm}$ above the apices of the upper canines and extended to the lateral nasal aperture the bone was removed. The segment should be mobilized only once the pre-maxilla is down-fracture, then manipulated and placed in its predetermined position guided by mock osteotomy on the casts.

Place and interdental wire around the teeth adjacent to the osteotomy, upper and lower teeth were put in occlusion by arch bars or I vey loop wire (IMF). The osteotomized segment was fixed in the desired position using two L-shaped $2.0 \mathrm{~mm}$ thickness titanium miniplates adapted passively to

Fig. 2.

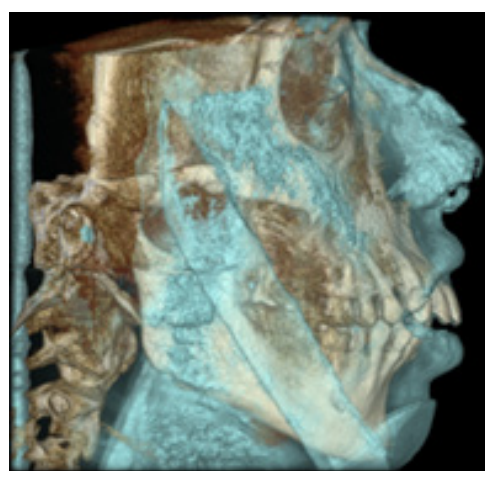

\section{RESULTS}

The Statistical analysis was performed with SPSS $16.0 \circledR$ (Statistical Package for Scientific Studies) for Windows. In this study, neither sloughing nor nonunion of the set-back segment was developed in any of the treated cases and no lateral bony defect. No periodontal involvement of the teeth adjacent or included in the osteotomy segment was observed. However, in a single case a $3 \mathrm{~mm}$ pocket was detected inter-proximally between the canine and second premolar. The incisional wounds showed satisfactory healing.

Blood loss was minimal and did not necessitate replacement during or after surgery. No localized infection was detected. Post-surgical edema was within normal limit and subsided completely within a week. Post-operative pain and discomfort was controlled satisfactory by analgesic.

Analysis of the skeletal and soft tissue changes following anterior maxillary osteotomy of all operated cases by CBCT software program revealed that: the bony contour and must be secured with 4 screws in each plate.

Depending on the esthetic requirements, the width of the alar base may need to be controlled by a cinch suture. The flap was then repositioned and sutured.

\section{Clinical and radiographic examination post- operative}

Clinical examination of the oral structures will undertake in a systemic fashion, lips, cheeks, tongue and palate will examine. Competence, texture and behavior of the lips will investigate. The position of the tongue at rest and function evaluated. Number, state and position of the teeth will be checked. The patient will be seat in an upright position with teeth in occlusion. The full face of the patient will be examine from frontal and profile directions.

Any degree of facial asymmetry or abnormality will observe. Cephalometric and cone beam computed tomography to evaluated and assessment of soft tissue changes after 6 months. (Fig 2,3).

Fig. 3.



Descriptive statistics of the different linear measurements through the study period are presented in Table $(1,2)$ and Figure (1).

There was a statistically significant increase in mean Nasal width after 6 months. From 6 months to 1 year, there was no change in mean Nasal width. Through the whole study period (Preoperative to 1 year), there was a statistically significant increase in mean Nasal width.

There was a statistically significant increase in mean Philtrum length after 6 months. From 6 months to 1 year, there was no change in mean Philtrum length. Through the whole study period (Pre-operative to 1 year), there was a statistically significant increase in mean Philtrum length.

There was a statistically significant increase in mean Nasolabial angle after 6 months. From 6 months to 1 year, there was no change in mean Nasolabial angle. Through the whole follow up period (Pre-operative to 1 year), there was a statistically significant increase in mean Nasolabial angle. 
AL-Omar, A.F. \& AL-Dakroroy, U. Soft tissue changes after anterior maxillary osteotomy by using 3D CBCT scanning. Int. J. Med. Surg. Sci., 4(4):1245-1250, 2017.

\section{Soft tissue landmarks}

Descriptive statistics of the soft tissue landmarks through the study period are presented in Table (12) and Figure (38). There was decrease in mean (Ls) after 6 months. No changes were observed form 6 months - 1 year.

Table. 1. Descriptive statistics of linear and angular measurements through the study period.

\begin{tabular}{lccc}
\hline Time & Pre-operative & 6 months & 1 year \\
Measurement & Mean \pm SD & Mean \pm SD & Mean \pm SD \\
\hline Nasal width $(\mathrm{mm})$ & $23.3 \pm 3.2$ & $24.2 \pm 3.1$ & $24.2 \pm 3.1$ \\
Philtrum length $(\mathrm{mm})$ & $18.2 \pm 1.7$ & $21.6 \pm 1.5$ & $21.6 \pm 1.5$ \\
Nasolabial angle $\left(^{\circ}\right)$ & $99.2 \pm 4$ & $104.3 \pm 4$ & $104.3 \pm 4$ \\
\hline
\end{tabular}

Table. 2. Mean \pm SD values of the changes after treatment in linear measurements.

\begin{tabular}{lllllll}
\hline Period & \multicolumn{2}{c}{ Pre-operative -6 months } & \multicolumn{2}{c}{6 months -1 year } & \multicolumn{2}{c}{ Pre-operative - 1 year } \\
Measurement & Mean \pm SD & $p$-value & Mean \pm SD & $P$-value & Mean \pm SD & $p$-value \\
\hline Nasal width $(\mathrm{mm})$ & $0.9 \pm 1.2$ & $0.025^{*}$ & $0 \pm 0$ & NCt & $0.9 \pm 1.2$ & $0.025^{*}$ \\
Philtrum length $(\mathrm{mm})$ & $3.3 \pm 0.7$ & $<0.001^{*}$ & $0 \pm 0$ & $\mathrm{NC}+$ & $3.3 \pm 0.7$ & $<0.001^{*}$ \\
\hline
\end{tabular}

*: Significant at $p \leq 0.05, \mathrm{NC}+$ : Not computed because all the measurements didn't change.

Table. 3. Mean \pm SD values of the changes after treatment in linear measurements.

\begin{tabular}{lcc}
\hline $\begin{array}{l}\text { Period } \\
\text { Point }\end{array}$ & $\begin{array}{c}\text { Pre-operative }-6 \text { months } \\
\text { Mean } \pm \text { SD }\end{array}$ & $\begin{array}{c}6 \text { months }-1 \text { year } \\
\text { Mean } \pm \text { SD }\end{array}$ \\
\hline SN & $3 \pm 0.5$ & $0 \pm 0$ \\
A $^{\prime}$ & $3 \pm 0.5$ & $0 \pm 0$ \\
LS & $3.3 \pm 0.6$ & $0 \pm 0$ \\
\hline
\end{tabular}

Fig. 1. Line chart representing changes in linear measurements through the study period.

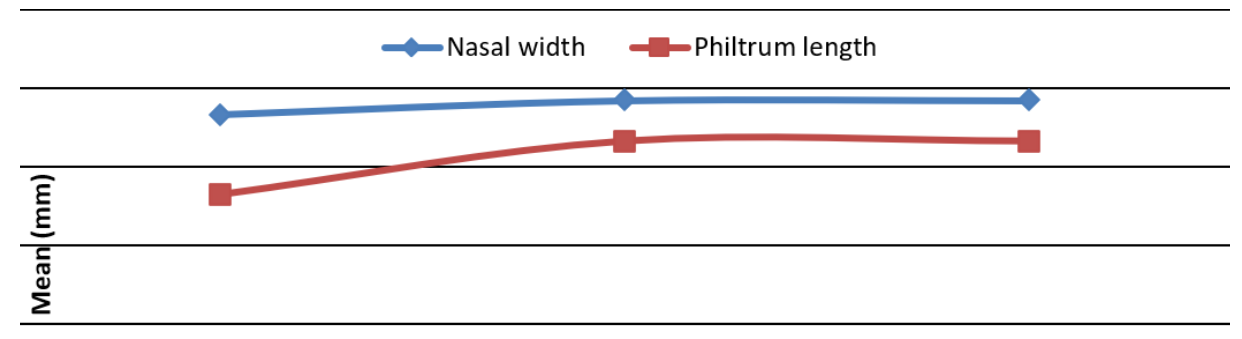

Fig. 2. Bar chart representing changes in soft tissue landmarks by superimposition.

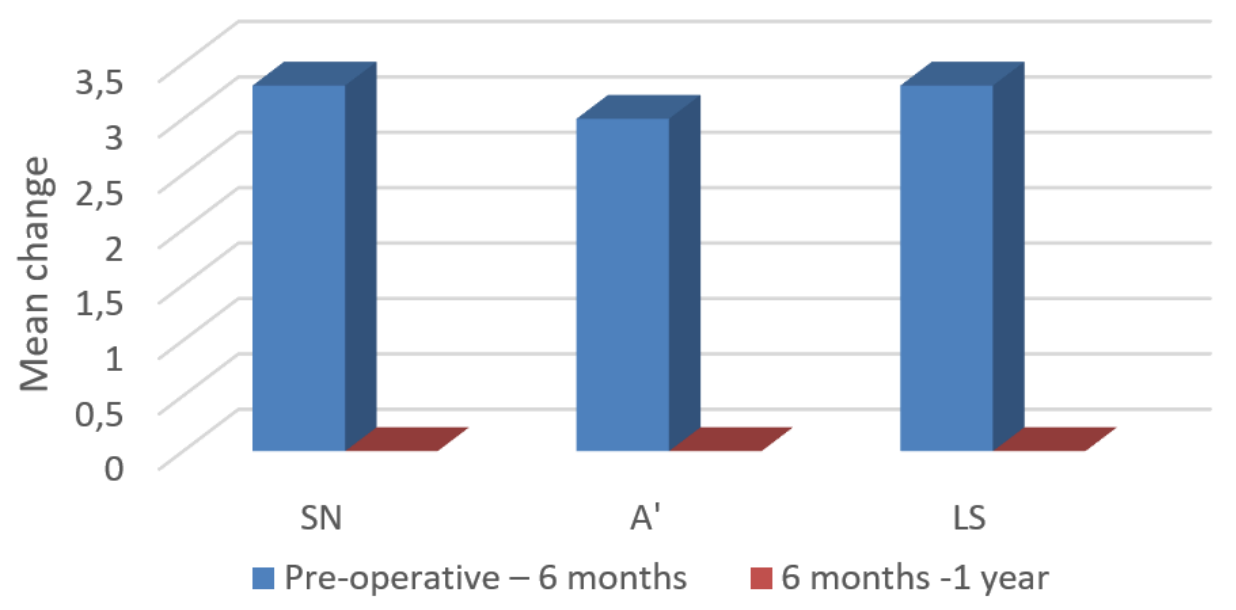




\section{DISCUSSION}

This study was conducted on six adult female patients, with age ranging from 21 to 27 years, average 24 years and average over-jet $9 \mathrm{~mm}$. They were selected on the basis that main problem was an excess of the anterior part of the maxilla and required surgical correction by anterior maxillary osteotomy. For each the following data were recorded: History, clinical examination, dental radiographic examination, orthodontic casts and mock surgery, photograph, cephalographs, cone beam computed tomography, to see accuracy measurement and reliability of bony landmark identification.

A higher proportion of female indicates that they are more concerned about their aesthetic appearance. Panula et al., (2001), after studying more patients of orthodontic surgery found that females were more concerned about their cosmetics than men. This is in accordance of this study that all cases were females.

In this study cone beam computed tomography used in evaluation of anterior maxillary osteotomy before and after surgery, it gave accuracy measurement and reliability of bony landmark identification. Cone beam computed tomography used in OMF surgery and orthodontics for numerous clinical applications, particularly for its low cost, easy accessibility and low radiation compared with multi-slice computerized tomography. This machine gives more views in the same exposure as panorama, cephalometric, posteroanterior and C.T. (Akpek et al., 2005; Sukovic, 2003)

In this study we used $3 \mathrm{D}$ CBCT in discussing the case with the patients before surgery and as predictive surgery. Park \& Hwang (2008) in their study reported Philtrum length changes following anterior segmental maxillary osteotomy. The philtrum length mean change was increased by $2.2 \mathrm{~mm}$ while it was $3 \mathrm{~mm}$ in this study. Nevertheless, Young claimed that care must be maintained in the selection for this kind of surgery of patients who have minimal vermilion border or long philtrum length.

Upper lip protrusion was found to decrease considerably with reduction of maxillary prognathism. This was a highly significant finding indicating a pleasing post-operative profile. Bell \& Dann (1973) in their extensive study report dropping back of the upper lip. Upper lip protrusion got reduced by $3.3 \mathrm{~mm}$ in the present study, while in Nadkarini's (1986) study, it got reduced by $3.1 \mathrm{~mm}$.

In this study, in none of the patient, a vascular necrosis of osteotomized segment occurred. This was due to the fact that all principles for preservation of vascular supply were followed. The surgical technique which maintained adequate vascularity to the osteotomized segment was used. We followed modified Cupar's "Down fracture" technique for anterior maxillary osteotomy. This technique has the advantage of preserving the palatal vascular supply and buccal vascular supply of osteotomized segment, the palatal pedicle and buccal pedicle must be maintained for premaxillary osteotomy and no vertical soft tissue incision to prevent postoperative bony defect in vertical osteotomized segment.

\section{CONCLUSION}

Through the modified segmental osteotomy technique, the upper lip was moved backward. The change of the upper incisor with the posterior movement of the anterior maxilla. The nasolabial angle was significantly increased by an average of $4.1^{\circ}$. The Philtrum length was significantly increased by an average $3.3 \mathrm{~mm}$. Flap modification during surgery; prevent any post-operative complications like bony defect and dehiscence. Cone Beam Computed Tomography can be used to obtain dimensionally accurate linear and angular measurement from bony maxillofacial structure and landmarks and allows accurate, three-dimensional imaging of hard and soft tissues.

AL-Omar, A.F. \& AL-Dakroroy, U. Cambios en los tejidos blandos después de la osteotomía maxilar anterior mediante el uso de la exploración 3D CBCT. Int. J. Med. Surg. Sci., 4(4):1245-1250, 2017.

RESUMEN: El objetivo de este estudio fue evaluar los cambios en los tejidos blandos después de la osteotomía maxilar anterior mediante tomografía computarizada con haz cónico. El estudio incluyó a doce pacientes diagnosticados que sufrían un exceso de la parte anterior del maxilar y requirió corrección quirúrgica mediante osteotomía maxilar anterior. Evaluación de la tomografía computarizada del haz cónico en la evaluación de los cambios de tejidos blandos. Todos los casos sometidos a osteotomía maxilar anterior con la técnica de Cuper modificada. El seguimiento de los casos se realizó de forma clínica y radiográfica mediante tomografía computarizada de haz cónico. Los resultados del estudio demostraron que el aumento estadísticamente significativo en el ángulo Nasolabial medio después de 6 meses fue de 5,2 grados, el valor medio del ancho nasal después de 6 meses fue de $0,9 \mathrm{~mm}$. El valor medio de la longitud de Philtrum fue de $3,3 \mathrm{~mm}$. En conclusión, la tomografía computarizada Cone Beam se puede utilizar para obtener mediciones lineales y angulares dimensionales precisas a partir de la estructura ósea maxilofacial ósea y permite obtener imágenes precisas y tridimensionales de los tejidos duros y blandos.

PALABRAS CLAVE: Tomografía computarizada del haz cónico; osteotomía maxilar anterior; tejido blando; problemas esqueléticos de clase II. 


\section{REFERENCES}

Akpek, S., Brunner, T., Benndorf, G., \& Strother, C. Three-dimensional imaging and cone beam volume CT in C-arm angiography with flat panel detector. Diagn. Inter. Radiol., 11(1):10-3, 2005.

Baba, R., Ueda, K., \& Okabe, M. Using a flat panel detector in high resolution cone beam CT for dental imaging. Dentomaxillofac. Radiol., 33(5):285-90, 2004.

Bell, W.H., \& Dann, J.J. Correction of dentofacial deformities by surgery in anterior part of the jaws. A study of stability and soft tissue changes. Am. J. Orthod.,64(2):162-187, 1973.

Boeddinghaus, R., \& Whyte, A. Current concepts in maxillofacial imaging. Eur. J. Radiol.,66(3):396-418, 2008.

Cupar, I. Die Chirurgische behandling der form und stellingsveran derungen des oberkiefers. Ost. Z. Stomatol., 51:565, 1954.

Finlay, P.M., Atkinson, J.M., \& Moos, K.F. Orthognathic surgery: Patient's expectations psychological pro $\neg$ file and satisfaction with outcome. Br. J. Oral Maxillofac. Surg., 33(1):9-14, 1995.

Fonseca, R., Dexter, H., Powers, M., \& Frost, D. Oral and maxillofacial trauma. 4 Ed. USA:Elsevier, 2012.

Flygare, L., \& Ohman, A. Preoperative imaging procedures for lower wisdom teeth removal. Clin. Oral Investig., 12(4):291-302, 2008.

Ganz, S. D. Computer-aided design computeraided manufacturing applications using CT and cone beam CT scanning technology. Dent. Clin. North Am., 52(4):777-808, 2008.

Kiyak, H.A., Vitaliano, P.P., \& Crinean, J. Patient's expectations as predictors of orthognathic surgery outcomes. Health Psychol.,7(3):251-68,1988.

Mohanc, A. M. Maxillary osteotomy in management of occlusal deformities. J. Oral Surg., 24(4):305-17, 1966.

Nadkaraini, P.G. Soft Tissue Profile Change Associated with orthognathic surgery for bimaxillary protrusion. J. Oral Maxillofac. Surg., 44(11):851-4, 1986.

Ouellette, P. L. Psychological ramifications of facial change in relation to orthodontic treatment and orthognathic surgery. J. Oral Surg., 36(10):78790, 1978.
Panula, K., Finne, K., \& Oikarinen, K. Incidence of complications and problems related to orthognathic surgery: a review of 655 patients. J. Oral Maxillofac. Surg., 59(10):1128-36, 2001.

Park, J. U., \& Hwang, Y. S. Evaluation of the soft and hard tissue changes after anterior segmental osteotomy on the maxilla and mandible. J. Oral Maxillofac. Surg., 66(1):98-103, 2008.

Sukovic, P. Cone beam computed tomography in craniofacial imaging. Orthod. Craniofac. Res.,6(1):316, 2003.

Polton, D. R. Surgical orthodontics, maxillary procedures. Angle. Orthod., 46(4):312-31, 1986.

White, S.C., \& Pharoah, M.J. Oral Radiology Principles and Interpretation. 6 ed. St Louis Missouri: Elsevier, 2008.

Wilmot, J.J., Barber, H.D., Chou, I.G., \& Vig, K. V. Associations between severity of dentofacial deformity and motivation for orthodonticorthognathic surgery treatment. Angle Orthod., 63(4):283-8, 1993.

Wunderer, S. Die prognathie operation mittels frontal gestieltem maxillfragment. Ost. Z. Stomatol., 59:98, 1962.

\section{Autor de correspondencia:}

Ahmed Fathi AL-Omar.

Department Of Oral and Maxillofacial Surgery king Khalid University Hospital, Dental University Hospital Faculty of Dentistry, King Saud University.

Tel.: (+96) 6566684840

E-mail: ahmed_alomar@hotmail.com

Conflictos de interés: None.

Financiamiento: None.

Recibido: 25-12-2017

Aceptado: 05-01-2018 